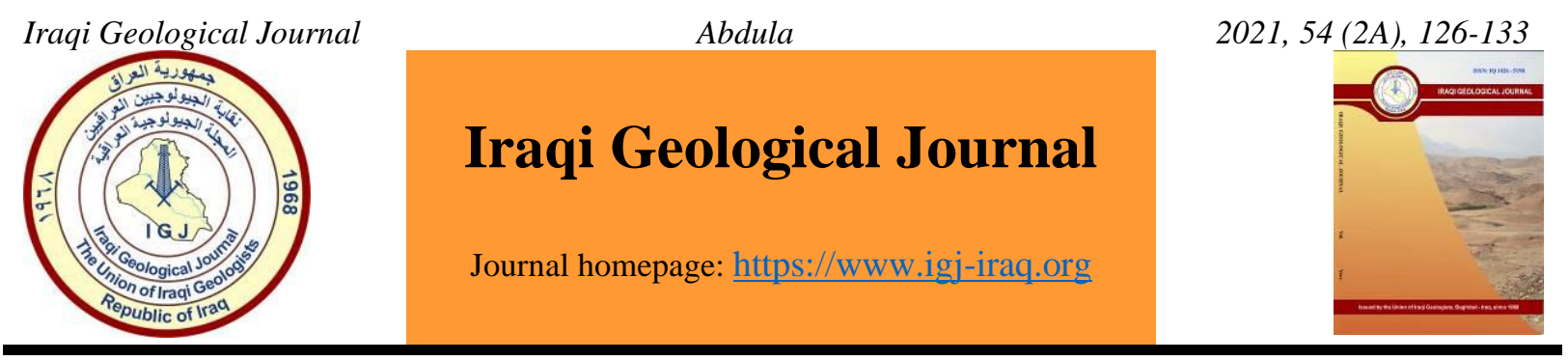

\title{
Speleology of Kospi Spi Cave in Northern Iraq
}

\author{
Rzger Abdulkarim Abdula ${ }^{1,2 *}$ \\ ${ }^{1}$ Petroleum Geoscience Department, Soran University, Erbil, Kurdistan Region, Iraq \\ ${ }^{2}$ Petroleum and Mining Engineering Department, Tishik International University, Erbil, Kurdistan Region, Iraq \\ * Correspondence: rzger.abdulkarim@tiu.edu.iq
}

Received: 25 March 2021; Accepted: 5 May 2021; Published: 31 July 2021

\begin{abstract}
The Kospi Spi Cave is situated in the well-karstified Qamchuqa limestone of the Cretaceous age. This study encompasses the facts on the medium sized cave. The entrance of the cave is located at 1,400 meters above sea level, the highest amongst the adjacent discovered caves. Its total sightseen extent is around 200 meters. The cave is a remnant gulp hole expanded by a sinking stream throughout the Late Neogene Time.
\end{abstract}

Keywords: Kospi Spi; Hanjirok; Pir Uswan; Karst; Cave; Iraq

\section{Introduction}

The Kospi Spi Cave is also known as Hanjirok or Pir Uswan. It was first recognized by Hamilton (1937). Since that time, it has not been visited by any investigator. A team from Soran University (Rzger A. Abdula, Halat R. Asaad, and Hema Y. Hassan), a photographer (Fareed Qadir), and a team from K24 TV investigated the cave on January 28, 2020. The cave is located within Tanun Mountain and $20 \mathrm{~km}$ east of Soran Town, Erbil Governorate with coordinates $36^{\circ} 38^{\prime} 33^{\prime \prime} \mathrm{N}$ and $44^{\circ} 39^{\prime} 21^{\prime \prime} \mathrm{E}$ (Fig. 1). The mountains in North Iraq were the inhabitants of initial humans since the early archaeological time; therefore, the area attracted archaeologists all over the world. In the early $20^{\text {th }}$ century. The archaeological investigations were initiated in the area by researchers from the United States and United Kingdom. These primary species of hominid, perhaps Homo erectus and Neanderthals in Shanidar Cave with discovered tools and artifacts from numerous sites crosswise north Iraq, add a new geographic perception to the study of the Paleolithic, Mesolithic and Neolithic times (Solecki, 1981; Solecki, 1998). The investigation in Shanidar Cave revealed remnants of the most primitive hominid that belong to Neanderthals (Murray, 2007). Moreover, two far ahead "proto-Neolithic" burials ground, one of which dates around 10,600 years ago were found in the same cave that contains 35 beings (Solecki et al., 2004). Confirmation from later times, Upper Paleolithic and Epipaleolithic, professions occurred in Palegawra, Zarzi, and Hazar Merd (Solecki, 1998). The field verifications for the alteration from the hunter-gatherer mode of life to sedentary food production in the area nearby the Mesopotamian Plain were revealed by Braidwood and Howe (1960). The German-Kurdish speleological inspection led by Laummans et al. (2008) can be considered as a primary investigation in the remarkable northern Iraq karst. The study leads to the exploration of 20 caves including Kuna Kamtiar, the lengthiest cave of Iraq, presently 5,060 $m$ in span. Nevertheless, up to this fact, slight consideration has been compensated to karst occurrences, DOI: $10.46717 /$ igj.54.2A.10Ms-2021-07-31 
so karst exploration and manipulation are quite at an initial step. This study aims to describe the Kospi Spi Cave geologically and to show its possibility to become a tourist site.

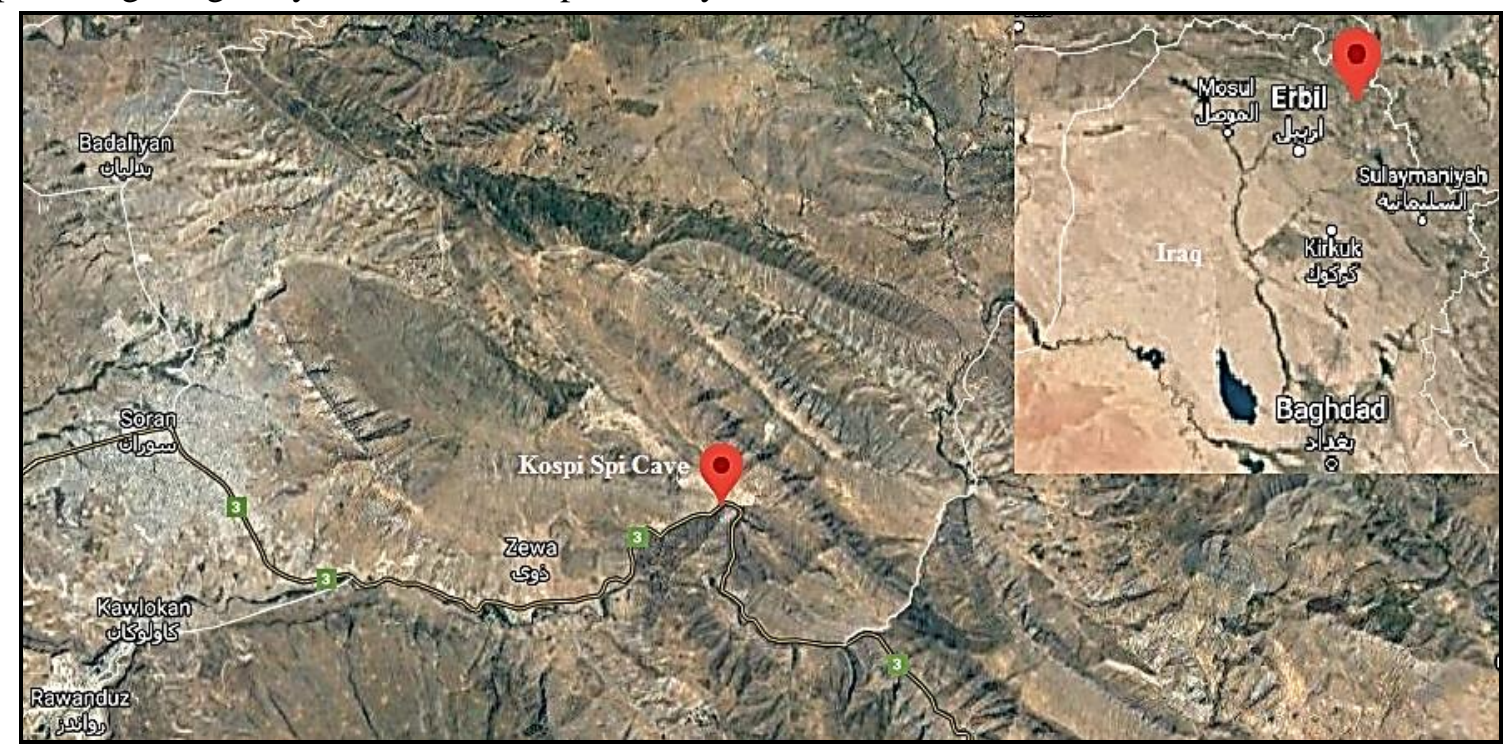

Fig. 1. Satellite image shows the location of the studied cave.

\section{Materials and Methods}

The study was based on direct observations. The location of the cave was determined by using Geographic Positioning System (GPS) and altitude was determined by using Google Map. The images of speleothem morphologies were taken by a regular camera.

\section{Results and Discussion}

\subsection{Geologic Setting}

Northern Iraq is situated on the northeastern edge of the Arabian Plate and it is a portion of the Alpine Mountain belt. This belt has a northwest-southeast direction in the northeastern part and an east-west direction in the northern part (Sissakian, 2019). The Zagros Mountains are the southern portion of the Alpine. The mountains were primarily formed by the collision between Eurasia and the Arabian plates (Scheffel and Wernet, 1988). This collision primarily occurred since the Late Cretaceous and is still ongoing that folded the existed bedrocks in the area (Scheffel and Wernet, 1988). The Tectonic characteristic of the High and Low Folded zones is the existence of double plunging anticlines, with folded assemblies and gorges in synclines. Exhaustive elevation of the sedimentary succession is the consequence of Alpine orogenic polyphase distortion (Stevanovic and Iurkiewicz 2004a).

The Imbricate Zone is located adjacent to the northern and northeastern borders of Iraq which is a sector of severe motion and diversity that encompasses pre-Mesozoic and to Late Cenozoic eras stratigraphic units. In the Imbricate and High Folded zones, the Balambo, Sarmord, and Qamchuga formations that were deposited during the late Lower Cretaceous (Aptian and Albian) and they are repeatedly immense and principally carbonate (limestones and dolomitic limestones). The lower and middle units of the Upper Cretaceous formations also comprise of carbonates, Kometan, Dokan, and Bekhme-Aqre, as well as mixed carbonate, Shiranish, and detrital sediments, Tanjero. An excessive tilting of stratums is due to exhaustive orogenic activities (Stevanovic and Markovic 2004).

The Kospi Spi Cave is located within the Imbricated Zone. The Imbricated (Crashed) Zone is boarded by asymmetrical anticlines and associated restricted synclines. The highest peak on the Zagros Mountain in Iraq is named Cheekha Dar which is $3611 \mathrm{~m}$ above sea level located $6 \mathrm{~km}$ north of Gundah 
Zhur Village and is on the boundary with Iran. Three main morphologic divisions can be recognized in Iraq: mountainous ranges, foothill pediments and agricultural plains (Numan, 2002; Stevanovic et al., 2009). The Zagros Mountains foothill spreads to Upper Mesopotamia which denotes an immense progressing plain. Its elevation ranges between 150 and 400 m.a.s.l. with numerous minor barred basins from which frequently there are no drainage passages (Stevanovic et al., 2009).

\subsection{Climatic Setting}

The climate of the northern Iraq is characterized by cold and rainy winters and dry-warm summers. The rains are carried in partially by cyclonic turbulences from the Mediterranean Sea and partially by movement nearby an area of high pressure in winter over the region (Hama et al., 2014). The Iraqi meteorological stations do not exist nearby Iran-Iraq border. The solitary climatic records obtainable is by Tali et al. (2016) which belong to Khaneh (Piranshahr) position east of Haji Omaran for the years 1995 to 2012 . The climatological statistics indicate that the mean annual temperature is $11.9^{\circ} \mathrm{C}$. They stated that the average lowest temperature is $4.1{ }^{\circ} \mathrm{C}$ and that the extreme is $14.4{ }^{\circ} \mathrm{C}$. The highest temperature is $39{ }^{\circ} \mathrm{C}$ and the lowest is $-28.6{ }^{\circ} \mathrm{C}$ in the area (Tali et al., 2016). The coldest month is January and the warmest month is July; therefore, the recommended time for tourist visiting is from early May to end late September. The regional precipitation increases with elevation in the mountains and ranges from about $300 \mathrm{~mm}$ per year in the outer foothills to more than 1,000 $\mathrm{mm}$ in the highest parts of the Halgurd and Sakran mountains. The precipitation reaches a maximum here not only because the mountains are high and massive, but also because the trend of the ranges shift from east to southeast. The storms which follow the outer flank of the range from the Mediterranean Sea eastward are forced to rise over the mountains or to be diverted sharply to the southeast (Wright, 1962; Hughes, 2018).

\subsection{Karstification and Karst Features}

Throughout Mesozoic and Tertiary periods, soluble rocks e.g. carbonate (limestone and dolomite) and evaporites (gypsum and anhydrite) were deposited in the area. This facilitated the improvement of karstification of surface and subsurface karstic morphology. The main cycle of karstification started during Paleocene Period. The second cycle of karstic process improvement has occurred through the Oligocene-Miocene Period and is active until the present. Alpine Orogeny instigated infiltration of superficial water by elevating and creating limestone anticlines. This penetration of water was enhanced by frequent fractures, joints and faults, and the expanding of the karstification. The elevating of carbonate ridges and their severe folding and faulting recurred in numerous stages (Stevanovic et al., 2009). The early stage was associated to the surface when the palaeo-drainage system was made and numerous cavernous gorges were fashioned accordingly. Additionally, specific climatic conditions, particularly with the exchange of periods of high humidity and dry seasons also enhanced karstification (Stevanovic and Iurkiewicz, 2004b). Climate changes throughout the year have enhanced the dissolution and precipitation. Furthermore, the karst development affected by high-latitude regions as the studied area (Kospi Spi Cave) $>1400 \mathrm{~m}$ (asl) of rapid warming in summer months and thick snow cover in winter months.

\subsection{Kospi Spi Cave}

It is one of the very few caves that is not well-known in the region and has never been visited by local scientists and visitor as well (Fig. 2). It is formed in the Qamchuqa massive limestone of the Cretaceous age. The total length of the main accessible channel is around $200 \mathrm{~m}$. The speleothemes and the size of the cave will be counted one of the most attractive sites in the region (Fig. 3). The entrance of Kospi Spi Cave is located at the highest altitude, 1,400 m.a.s.l., among the currently explored caves (Fig. 4). Owing to its location being considerably higher than the real erosional base level, the cave is 
virtually entirely desiccated; consequently, solitary filtration water might be observed after heavy rainfalls. A number of analogous intra-bedded cave openings join to one small and poorly expanded primary conduit which progressively excavates towards the depression at its end. The location and direction of that passage designate that the penetrated water was the chief reason of creating the cave (Fig. 5). Therefore, the cave is a remnant swallow hole developed by a dropping creek throughout the Late Neogene and Pleistocene ages by widening and dipping the water path, the tectonics had a substantial role as well in the cave inception.

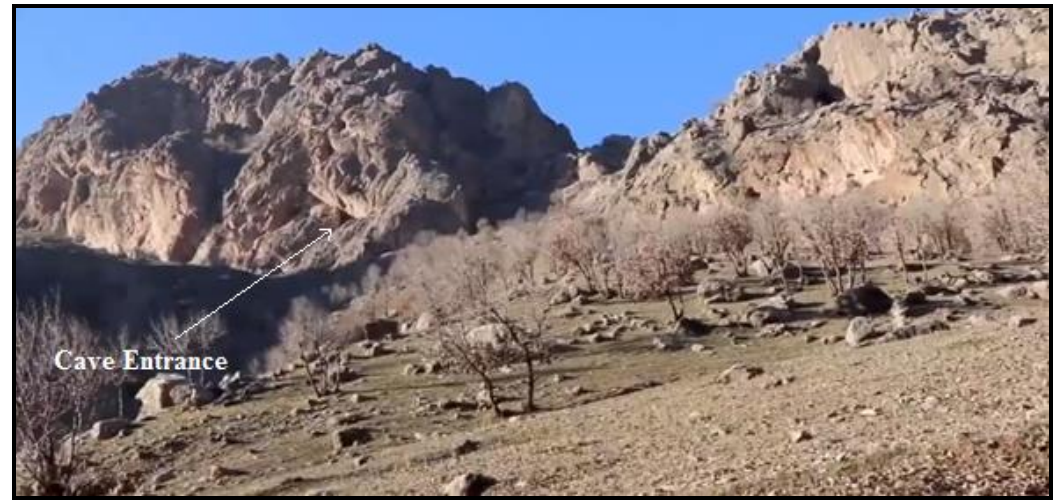

Fig. 2. Field photo of the cave from outside

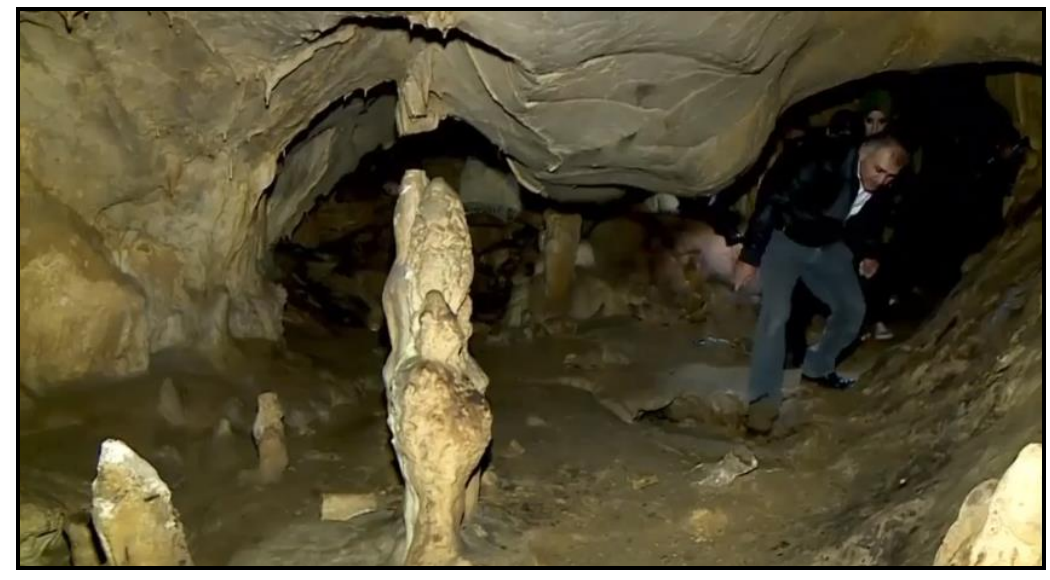

Fig. 3. The interior appearance shows the size of the cave

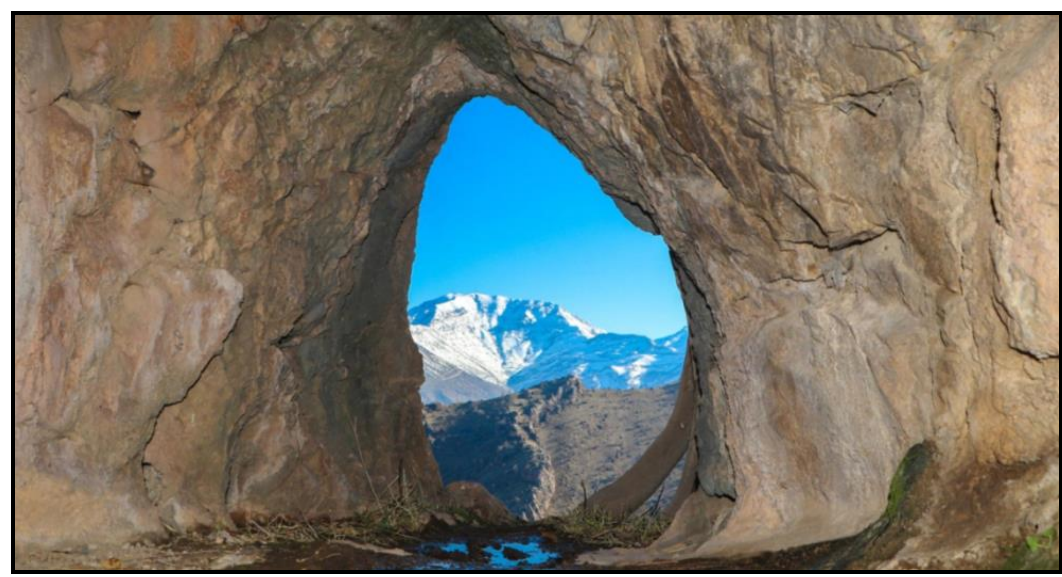

Fig. 4. The outside view from inside the cave and shows the entrance of the cave 


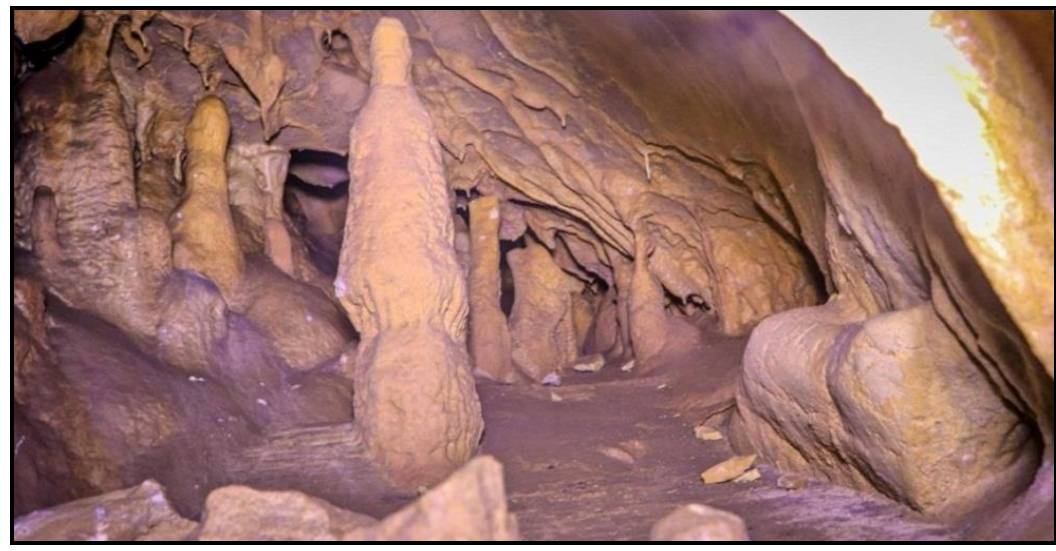

Fig. 5. The orientation of the channel, the infiltrated water was the main factor originating the cave

\subsection{Speleothem Morphologies}

Some of the speleothem morphologies that have been found in the cave are:

\subsubsection{Flowstone}

They are speleothems (mineral deposits) composed of calcium carbonate on the sides or roof of a cave fashioned from a steady movement of water over a comparatively wide area (Hill and Forti, 1997) (Fig. 6).

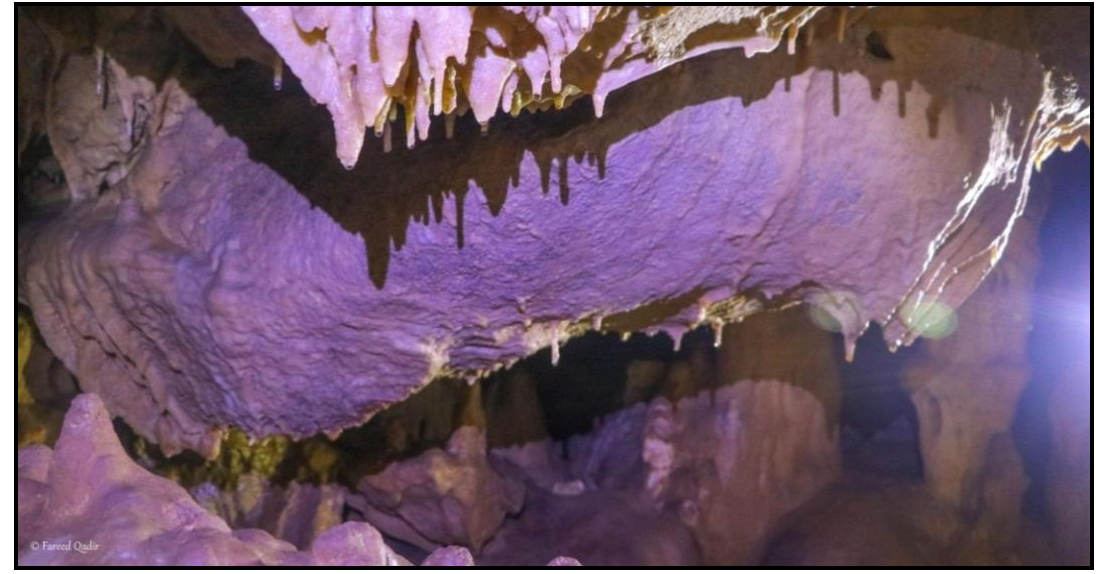

Fig. 6. Flowstones on the walls and roof of the cave formed from a gradual flow of water.

\subsubsection{Helictite}

It is composed of calcium carbonate in a pothole that occurs in a twisted form (Fig. 7), like a helix, apparently resisting the gravity law (Davis, 2012).

\subsubsection{Stalactite}

The word stalactite derives from the Greek word stalaktos that means "dripping", due to drip of water from the top of carbonate caves. Principally, the acidic water that formed by reaction between water and carbon-dioxide forming a carbonic acid and acting as dissolving agent. These deposits become harder and accumulate gradually to form stalactite (Frisia, 2019) (Fig. 8). 


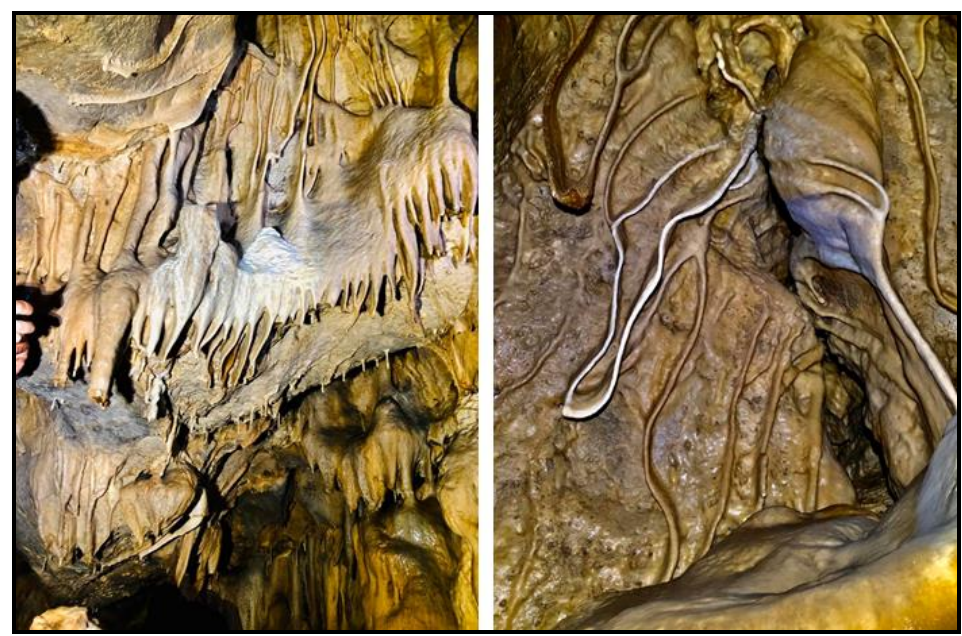

Fig. 7. The left side is a whole appearance and the right side is an enlarged image of helictite.

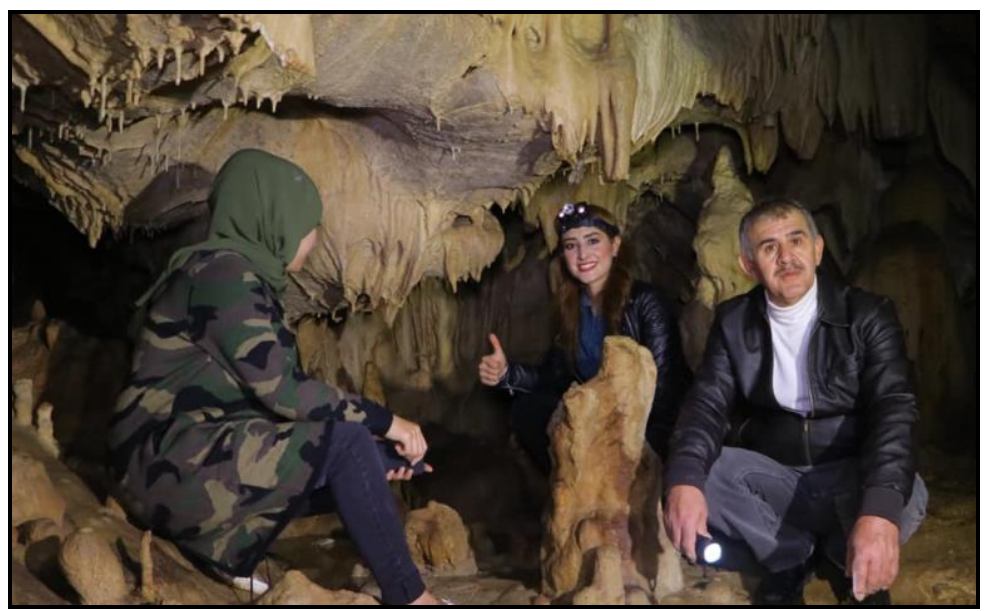

Fig. 8. Accumulation of calcium carbonate through a long time to form a stalactite.

\subsubsection{Stalagmite}

The term stalagmite comes from the Greek word, stalagma, to "drop". Stalagmite is a column of rock that rises from the floor of a cave, formed over a very long period of time by drops of water containing lime falling from the roof of the cave on the floor grow from the ground by accumulation of calcium carbonate, from acidic water falls from the top of the cave (Frisia, 2019) (Fig. 9).

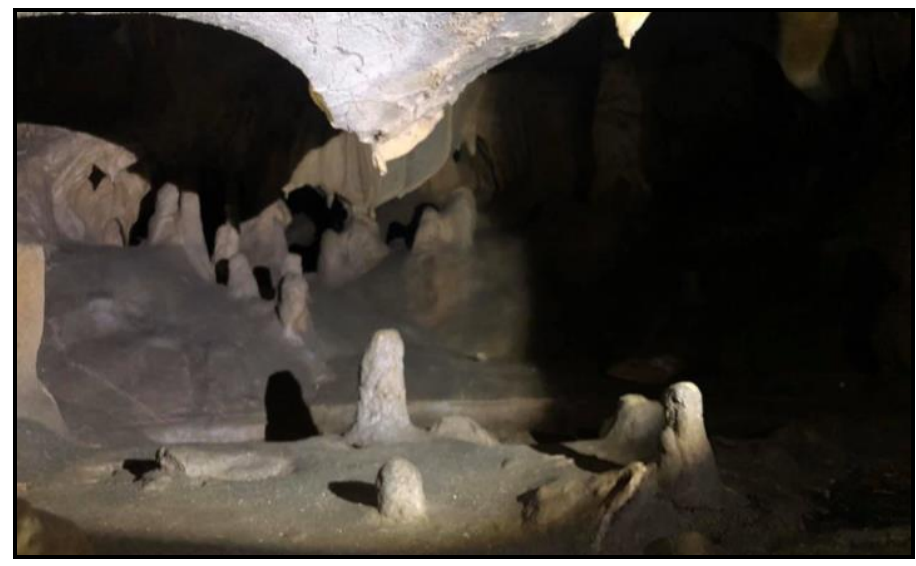

Fig. 9. Calcium carbonate rise from the floor of the cave over time to form stalagmites 


\subsubsection{Column}

Occasionally stalactites and stalagmites continue in growing on both directions of one or both may eventually result in a junction and the formation of a pillar or column of rock that becomes massive and dense (Hill, and Forti, 1997) (Fig. 10).

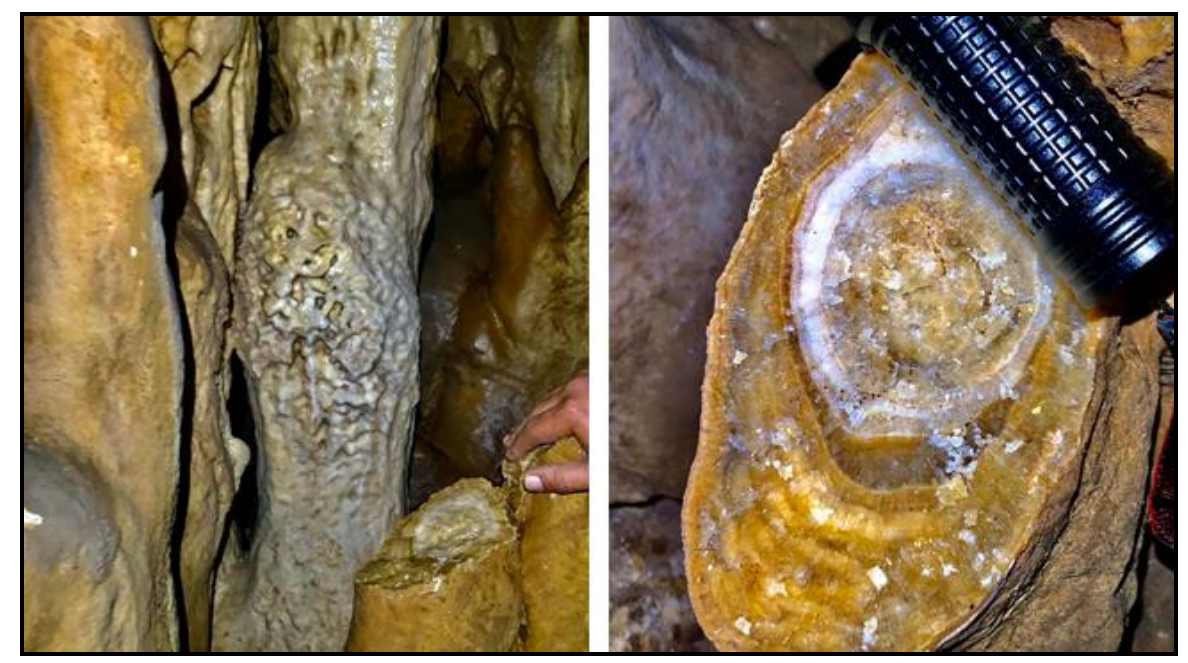

Fig. 10. Stalactites and stalagmites meet forming a pillar or column. The left side displays a column and the right side shows horizontal cross-section of a column

\subsection{Significance of the Cave}

The cave is located in a proper geographic site which is very close to the main Erbil to Haj Omran Road (the old path known as Hamilton International Road). It is about one kilometer far away from the paved road that heads to the Pir Uswan Village (Fig. 1). The cave has a very nice view and contains a lot of spectacular speleothem morphologies. The surrounding area of the cave is beautiful and suitable for becoming a tourist area by providing the appropriate parking area, footway from the main road to the cave, cafeteria, and providing utilities (electricity, drinkable water, and rest rooms). Furthermore, the walkways should be provided inside the cave by making wood ladder and footpaths.

\section{Conclusions}

Although more than half of the northern Iraq is covered by carbonate rocks with the variable extent of karstification, the caves are generally not investigated by the researchers. The Kospi Spi Cave was a result of exhaustive groundwater movement and well developed karstification after the Alpine Orogeny movements. The cave was carved within the carbonates of the Qamchuqa Cretaceous Formation. The study encourages attention in additional work and inspires the Municipalities and Tourism and the Culture, Tourism and Antiquities ministries in Kurdistan Region and Iraq, respectively.

\section{Acknowledgements}

The author thanks Mr. Fareed Qadir and the K24 TV team for the photography and escorting in the cave investigation and accompanying him. The authors are very grateful to the Editor in Chief Prof. Dr. Salih M. Awadh, the Secretary of Journal Mr. Samir R. Hijab. and the Technical Editors for their great efforts and valuable comments.

\section{References}

Braidwood, J.R. and Howe, B., 1960. Prehistoric investigation in Iraqi Kurdistan-Oriental Institute of University of Chicago, Studies in ancient oriental civilization, 31, University of Chicago press, Chicago, Illinois, 184 pp. 
Davis, D.G., 2012. Helictites and related speleothems, $2^{\text {nd }}$ edition, in: White, W.B. and Culver, D.C., Encyclopedia of Caves, Academic Press, Amsterdam, 379-383.

Frisia, S. 2019. Stalactites and stalagmites, $3^{\text {nd }}$ edition, in: White, W.B. and Culver, D.C., Encyclopedia of Caves, Academic Press, Amsterdam, 1041-1048.

Hama, R.H., Hamad, R.T., and Aziz, F.H., 2014. Climate change in relation to rainfall and temperature in Erbil Province, Kurdistan, Iraq, Tunisian Association of Digital Geographic Information, $8^{\text {th }}$ International Congers Geo Tunis, Tunis, 8.

Hamilton, A.M., 1937. Road through Kurdistan: The Narrative op an Engineer in Iraq, London, Faber and Faber Ltd., 12s. 6d., 331pp.

Hill, C.A. and Forti, P., 1997. Cave Minerals of the World, $2^{\text {nd }}$ edition, Huntsville, Alabama: National Speleological Society Inc., 217-225.

Hughes, P.D., 2018. Little Ice Age glaciers and climate in the Mediterranean mountains, Cuadernos de Investigación Geográfica, 44 (1), 15-45.

Laumanns, M., Rasch, A. and Audra, P., 2008. Karst and caves of Iraq (including the results of a 2007 Kurdish-German speleological project and an overview on hypogenic sulphidic speleogenesis), Berliner Höhlenkundliche Berichte, 26, Berlin.

Murray, T., 2007. Milestones in Archaeology: A Chronological Encyclopedia, ABC-CLIO, 639 pp.

Numan, N.M.S., 2002, Tectonic investigations in northern Iraq-Report, FAO North Documentation Fund, Erbil (unpublished).

Scheffel, R. and Wernet, S. (editors), 1988. Natural Wonders of the World, The Reader's Digest Association, Inc., New York, USA, 463p.

Sissakian, V. K., 2019. Shanidar Cave: An interesting archeological site in Iraqi Kurdistan Region, UKHJSE, 3 (2), 01-09.

Solecki, Ralph, 1998. Archaeological survey of caves in Northern Iraq, International Journal of Kurdish Studies, 12 (1), 1-70.

Solecki, Rose, 1981. An Early Village Site at Zawi Chemi Shanidar, Bibliotheca Mesopotamica, 13, Undena Publications, Malibu.

Solecki, R.S., Solecki, R.L., and Agelarakis, A.P., 2004. The Proto-Neolithic cemetery in Shanidar Cave, Texas A\&M University Press, $256 \mathrm{pp}$.

Stevanovic, Z. and Iurkiewicz, A., 2004a. Geologic-tectonic factors controlling groundwater flow patterns and discharge of karst aquifers in Western Zagros (Northern Iraq), Proceedings of $33^{\text {rd }}$ IAH Congress $\& 7^{\text {th }}$ ALHSUD (CD) Zacatecas.

Stevanovic, Z. and Iurkiewicz, A., 2004b. Karst of Iraqi Kurdistan-distribution, development and aquifers, Receuil de raports, Vol. VIII, Special edition, Serbian Academy of Sciences and Arts, b. DCLVI, 2, Belgrade, $31-53$

Stevanovic, Z., Iurkiewicz, A., and Maran, A., 2009. New insights into karst and caves of northwestern Zagros (northern Iraq), Acta Carsologica, 38 (1), 83-96.

Stevanovic, Z. and Markovic, M., 2004. Hydrogeology of northern Iraq, Vol. 1. Climate, hydrology, geomorphology and geology, Spec. edition TCES, FAO/UN, Rome.

Tali, M.G., Naeimi, A., and Gharnaie, R.H., 2016. Glacial landforms in border mountainous areas between Iran and Iraq. Asian Journal of Earth Sciences, 9, 16-26.

Wright, H.E., 1962. Pleistocene glaciation in Kurdistan, Eiszeitalter und Gegenwart, 12, 131-164. 